\title{
Glycine functionalized alumina nanoparticles stabilize collagen in ethanol medium
}

\author{
S PRABHU, K CHEIRMADURAI, J RAGHAVA RAO and P THANIKAIVELAN* (D \\ Central Leather Research Institute (Council of Scientific and Industrial Research), Adyar, Chennai 600 020, India
}

MS received 15 May 2015; accepted 9 September 2015

\begin{abstract}
The synthesis of glycine functionalized $\mathrm{Al}_{2} \mathrm{O}_{3}$ nanoparticles $\left(\mathrm{Gly}_{\mathrm{N}} @ \mathrm{Al}_{2} \mathrm{O}_{3}\right)$ by a simple two-step process employing sucrose as a template was reported. The functionalization of $\mathrm{Al}_{2} \mathrm{O}_{3}$ nanoparticles with glycine was confirmed by Fourier transformed infrared (FT-IR) spectroscopy, X-ray diffraction, high-resolution scanning electron

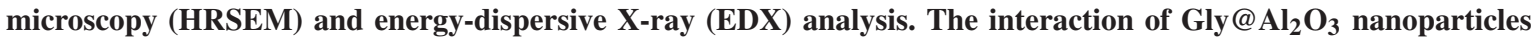
with collagen fibres was demonstrated using HRSEM, EDX, differential scanning calorimetry and FT-IR analysis. The thermal stability of collagen is enhanced to $74^{\circ} \mathrm{C}$ upon interaction with $\mathrm{Gly} @ \mathrm{Al}_{2} \mathrm{O}_{3}$ nanoparticles thereby suggesting applications in leather making, biomedicine and cosmetic fields.
\end{abstract}

Keywords. Nanoparticles; stabilization; protein; functionalization; thermal stability.

\section{Introduction}

Collagen is a naturally occurring skin protein in animal tissue [1]. Collagen, a building block of skin matrix, plays vital role in many applications including leather making, tissue engineering and cosmetics. The triple helical structure of collagen is stabilized by inter- and intra-molecular hydrogen bonding interactions [2]. Collagen will destabilize on exposure to heat or specific enzymes such as collagenase. Destabilization of collagen can be overcome by adopting several methods like chemical [3] or physical [4] crosslinking. Only very few metal salts and select organic molecules can stabilize the collagen matrix and improve its hydrothermal stability [5-7]. Industrial processes such as leather manufacturing involve usage of huge amount of water in different stages of tanning process. The used water after tanning process is contaminated by the presence of chromium(III) and many different chemicals used in leather processing. This contaminated water will cause environmental pollution and the chromium needs to be recycled [8]. Further, the availability of water is decreasing over the years and it has been estimated that 1.8 billion people will live in countries or regions with absolute water scarcity by $2025 \mathrm{AD}$ [9]. To overcome this challenge, chromium-free, water-less $[10,11]$ and other greener approaches are being developed. Although aluminium tanning is known, it is not widely practiced owing to its reversible reaction with collagen [7].

\footnotetext{
*Author for correspondence (thanik8@yahoo.com; thanik@clri.res.in)
}

Stabilization of collagen using nanoparticles offers ideal platform for swapping not only chromium usage in tanning but also water medium [12,13] since most nanoparticles disperse well in organic solvents rather than in water. $\mathrm{SiO}_{2}$ nanoparticles were used to crosslink the collagen and enhance the thermal stability significantly [14]. The use of functionalized iron oxide nanoparticles for collagen stabilization both in aqueous and non-aqueous media was in recent times [15,16]. Castaneda et al [17] reported the crosslinking of collagen using tiopronin-modified gold nanoparticles via 1-ethyl-3(3-dimethylaminopropyl)-carbodimide (EDC). Functionalization of nanoparticles gains additional benefit due to stabilization, high dispersion in solvents and prevents uncontrolled agglomeration of the nanoparticles [18].

Herein, the synthesis of glycine functionalized $\mathrm{Al}_{2} \mathrm{O}_{3}$ (Gly@ $\mathrm{Al}_{2} \mathrm{O}_{3}$ ) nanoparticles for the stabilization of collagen fibres in non-aqueous medium was reported. Glycine was chosen for the functionalization of $\mathrm{Al}_{2} \mathrm{O}_{3}$ nanoparticles due to its small size, bi-functional group and biodegradable nature. It is proposed that the carboxyl groups of glycine can easily adsorb on the surface of the nanoparticles and amino groups could interact with the collagen molecule [19]. $\mathrm{Al}_{2} \mathrm{O}_{3}$ was first synthesized using sucrose as a template and then it is functionalized with glycine. The prepared Gly@ $\mathrm{Al}_{2} \mathrm{O}_{3}$ nanoparticles were characterized using Fourier transformed infrared (FT-IR), X-ray diffraction (XRD), thermogravimetric analysis (TGA), high-resolution scanning electron microscopic (HRSEM) and energy-dispersive X-ray (EDX) analysis. The Gly@ $\mathrm{Al}_{2} \mathrm{O}_{3}$ nanoparticles were dispersed in ethanol and treated with collagen fibres for stabilization. The treated fibres were further characterized using FT-IR, HRSEM, EDX and differential scanning calorimetric (DSC) analysis. 


\section{Materials and methods}

\subsection{Materials}

The collagen fibres (hide powder) were prepared as described elsewhere [15]. Aluminium sulphate $\left(\mathrm{Al}_{2}\left(\mathrm{SO}_{4}\right)_{3} \cdot 16 \mathrm{H}_{2} \mathrm{O}\right)$ was procured from Merck Ltd., India. Sucrose was procured from HiMedia Laboratories, India. Glycine was procured from SD Fine-Chem, India. All chemicals and reagents were analytical grade and used as such without further purification. Deionized and distilled water was used throughout the experiment.

\subsection{Preparation of $\mathrm{Al}_{2} \mathrm{O}_{3}$ and glycine functionalized $\mathrm{Al}_{2} \mathrm{O}_{3}\left(\mathrm{Gly}_{\mathrm{N}} \mathrm{Al}_{2} \mathrm{O}_{3}\right)$}

$\mathrm{Al}_{2} \mathrm{O}_{3}$ was prepared according to the reported procedure [20] with modifications. Initially, $4.275 \mathrm{~g}(0.0125 \mathrm{~mol})$ of sucrose (template) was dissolved in $50 \mathrm{ml}$ distilled water. Then $7.864 \mathrm{~g}(0.0125 \mathrm{~mol})$ of $\mathrm{Al}_{2}\left(\mathrm{SO}_{4}\right)_{3} \cdot 16 \mathrm{H}_{2} \mathrm{O}$ was added and stirred vigorously for $30 \mathrm{~min}$ at $30^{\circ} \mathrm{C}$. Then, $\mathrm{pH}$ of the above mixture was adjusted to 7 using aq. $\mathrm{NaOH}$ solution and stirred for $1 \mathrm{~h}$. The stirred mixture was then heated at $100^{\circ} \mathrm{C}$ to remove water and other volatiles. The resulting solid was then calcined at $600^{\circ} \mathrm{C}$ for $6 \mathrm{~h}$ to remove the template. The obtained solid particles $\left(\mathrm{Al}_{2} \mathrm{O}_{3}\right)$ were washed with water thrice and once with ethanol and then dried at $100^{\circ} \mathrm{C}$ in hot air oven for $5 \mathrm{~h}$. For the functionalization of $\mathrm{Al}_{2} \mathrm{O}_{3}$, $250 \mathrm{mg}$ glycine and $250 \mathrm{mg} \mathrm{Al} \mathrm{O}_{3}$ were mixed in $15 \mathrm{ml}$ ethanol and stirred for $3 \mathrm{~h}$ at $30^{\circ} \mathrm{C}$. The $\mathrm{pH}$ of the mixture was measured to be around 6.5. The mixture was centrifuged to obtain white solid particles. Particles were washed with ethanol thrice to remove the un-coated glycine. The obtained product $\left(\mathrm{Gly} @ \mathrm{Al}_{2} \mathrm{O}_{3}\right.$ ) was then dried under vacuum for overnight. The products were stored in clean vial and characterized.

\subsection{Interaction of $\mathrm{Gly} @ \mathrm{Al}_{2} \mathrm{O}_{3}$ with collagen}

In a typical procedure, $10 \mathrm{mg}(10 \mathrm{wt} \%)$ of Gly@ $\mathrm{Al}_{2} \mathrm{O}_{3}$ nanoparticles were sonicated in $5 \mathrm{ml}$ ethanol for $15 \mathrm{~min}$ to achieve complete dispersion of the nanoparticles in the solvent. Then, $100 \mathrm{mg}$ of collagen fibres (hide powder) were added to the above mixture and stirred for $2 \mathrm{~h}$. For comparison, pure $\mathrm{Al}_{2} \mathrm{O}_{3}$ nanoparticles were used instead of Gly@ $\mathrm{Al}_{2} \mathrm{O}_{3}$ nanoparticles in the above procedure for finding out the efficacy of interaction with collagen. The samples were then investigated for thermal stability, structure and morphology analysis.

\subsection{Characterization of materials}

XRD measurements were recorded using a Rigaku Miniflex (II) desktop diffractometer (Ni filtered $\mathrm{CuK} \alpha$ radiation with $\lambda=0.154060 \mathrm{~nm}$ ) in the $2 \theta$ range from $10^{\circ}$ to $80^{\circ}$ with scan rate of $0.2 \mathrm{deg} \mathrm{min}^{-1}$. XRD patterns were compared with the Joint Committee on Powder Diffraction Standards (JCPDS) data for phase identification. TGA of the synthesized Gly@ $\mathrm{Al}_{2} \mathrm{O}_{3}$ nanoparticles was carried out using TGA Q50 (V20.13 Build 39, TA Instruments). About $6 \mathrm{mg}$ of the sample was heated under nitrogen atmosphere at a heating rate of $20^{\circ} \mathrm{C} \mathrm{min}-1$. The analysis was carried out from 30 to $800^{\circ} \mathrm{C}$. FT-IR spectra of the samples were recorded using Perkin Elmer instrument. The samples were ground with $\mathrm{KBr}$ and compressed to form pellets. The pellets were analysed in a single beam mode at the range of 400$4000 \mathrm{~cm}^{-1}$ with an average of four scans and $2 \mathrm{~cm}^{-1}$ resolution. HRSEM analysis was carried out using a FEI Quanta (FEG 200) microscope. Before analysis, the samples were coated with gold. DSC analysis of the wet samples was carried out using a NETZSCH (DSC 204) instrument with scan rate of $2^{\circ} \mathrm{C} \min ^{-1}$.

\section{Results and discussion}

\subsection{Characterization of $\mathrm{Al}_{2} \mathrm{O}_{3}$ and $\mathrm{Gly} @ \mathrm{Al}_{2} \mathrm{O}_{3}$}

XRD patterns of $\mathrm{Al}_{2} \mathrm{O}_{3}$ and $\mathrm{Gly} @ \mathrm{Al}_{2} \mathrm{O}_{3}$ are shown in figure 1a. All the diffraction peaks of $\mathrm{Al}_{2} \mathrm{O}_{3}$ are in good agreement with cubic $\gamma-\mathrm{Al}_{2} \mathrm{O}_{3}$ (JCPDS no. 29-0063). The broad diffraction peaks in the pattern suggest that the particles are in nanosize. The diffraction patterns of $\mathrm{Gly}_{0} @ \mathrm{Al}_{2} \mathrm{O}_{3}$ clearly show the presence of both $\gamma-\mathrm{Al}_{2} \mathrm{O}_{3}$ and glycine. Indeed, most of the diffraction peaks of $\mathrm{Al}_{2} \mathrm{O}_{3}$ appear to be weak and masked with sharp and strong peaks of glycine. The peaks of glycine in the XRD pattern of $\mathrm{Gly} @ \mathrm{Al}_{2} \mathrm{O}_{3}$ nanoparticles can be assigned to $\gamma$-glycine, a thermodynamically stable form (JCPDS no. 06-0230) [21]. The crystallite size of the nanoparticles were quantitatively calculated using Scherrer's formula using full-width at half-maximum intensity (FWHM) of (400) phase for $\gamma-\mathrm{Al}_{2} \mathrm{O}_{3}$ [22]. The calculated sizes are 3.6 and $5.8 \mathrm{~nm}$ for $\mathrm{Al}_{2} \mathrm{O}_{3}$ and $\mathrm{Gly} @ \mathrm{Al}_{2} \mathrm{O}_{3}$, respectively.

FT-IR spectra of pure glycine, $\mathrm{Al}_{2} \mathrm{O}_{3}$ and Gly $@ \mathrm{Al}_{2} \mathrm{O}_{3}$ are shown in figure $1 \mathrm{~b}$. Pristine $\mathrm{Al}_{2} \mathrm{O}_{3}$ nanoparticles show characteristic broad $\mathrm{Al}-\mathrm{O}-\mathrm{Al}$ and $\mathrm{Al}-\mathrm{O}$ bands in the range of $500-800 \mathrm{~cm}^{-1}$. The characteristic peaks of glycine at $1332\left(\omega \mathrm{CH}_{2}\right), 1412\left(v_{\mathrm{s}} \mathrm{COO}^{-}\right), 1503\left(\delta_{\mathrm{s}} \mathrm{NH}_{3}\right)$ and 3169 $\left(v_{\mathrm{s}} \mathrm{NH}_{3}\right) \mathrm{cm}^{-1}$ are in agreement with the earlier report [19]. The signature peaks of $\gamma$-glycine corresponding to $-\mathrm{COO}^{-}$ rocking, $-\mathrm{COO}^{-}$bending, $\mathrm{CCN}$ stretching and $\mathrm{CH}_{2}$ rocking are seen at 500,685, 890 and $930 \mathrm{~cm}^{-1}$, respectively [21]. The Gly@ $\mathrm{Al}_{2} \mathrm{O}_{3}$ nanoparticles exhibit characteristic peaks of both glycine and alumina as marked with lines and box in figure $1 \mathrm{~b}$. This observation confirms the functionalization of glycine on the surface of $\mathrm{Al}_{2} \mathrm{O}_{3}$ nanoparticles. The broad band between 3800 and $3000 \mathrm{~cm}^{-1}$ may be due to the hydrogen bonding present in the product.

HRSEM images of $\mathrm{Al}_{2} \mathrm{O}_{3}$ and $\mathrm{Gly}_{0} \mathrm{Al}_{2} \mathrm{O}_{3}$ nanoparticles at low and high magnifications are shown in figure 2 . The $\mathrm{Al}_{2} \mathrm{O}_{3}$ nanoparticles seem to be very fine with spherical shape having an average particle size of $20 \pm 3 \mathrm{~nm}$. 


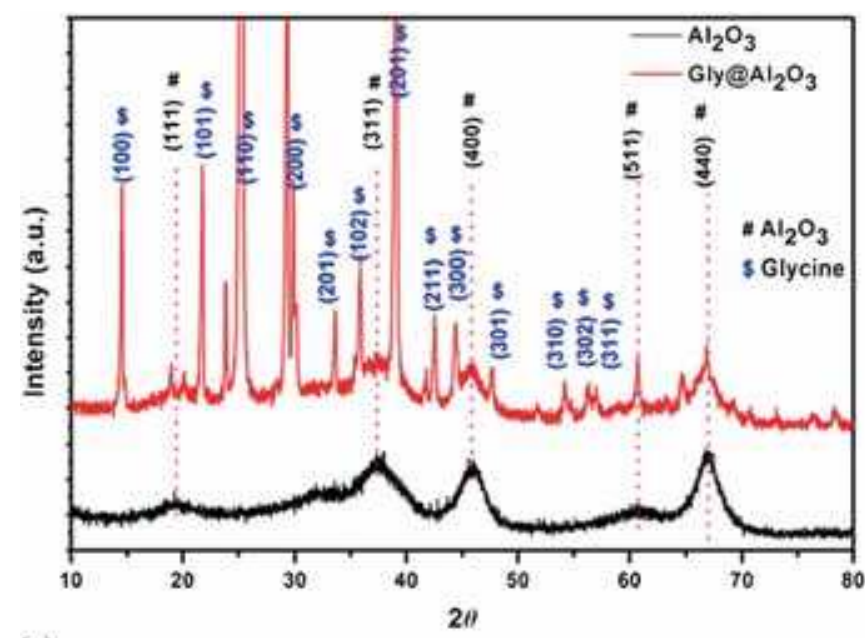

(a)

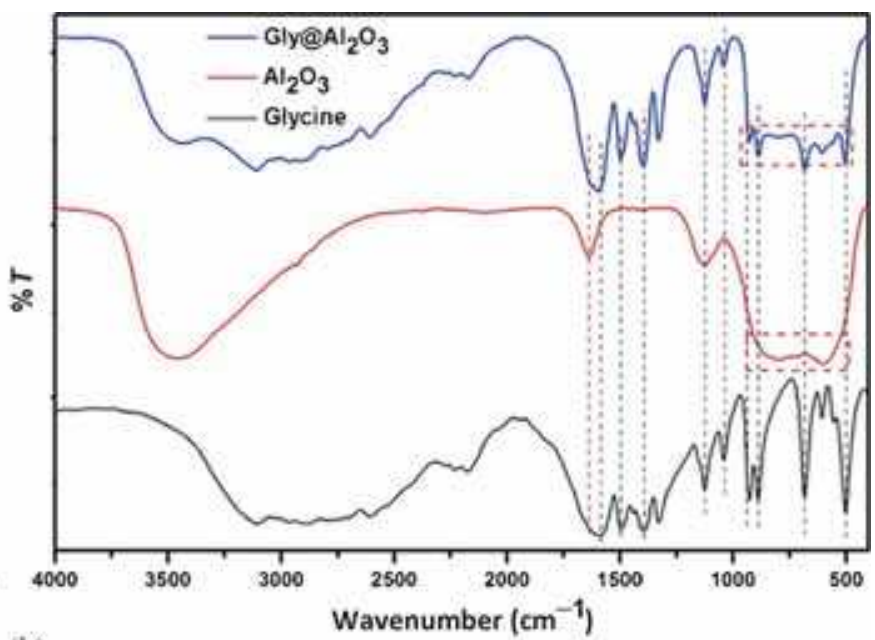

(b)

Figure 1. (a) XRD and (b) FT-IR spectra of $\mathrm{Al}_{2} \mathrm{O}_{3}$ and $\mathrm{Gly} @ \mathrm{Al}_{2} \mathrm{O}_{3}$ nanoparticles.
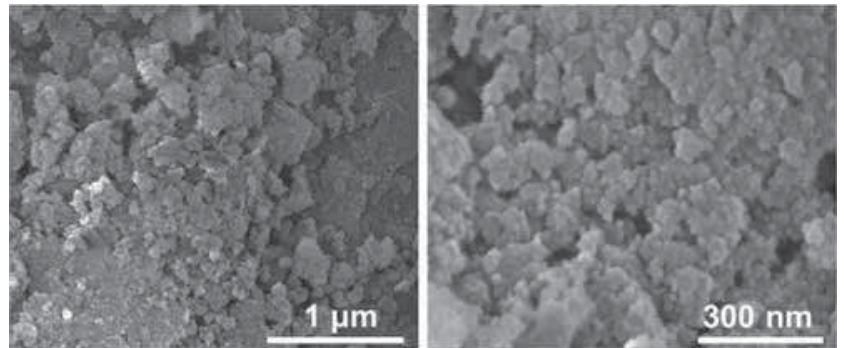

(a)

(b)

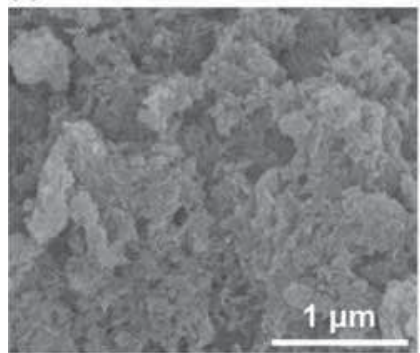

(c)

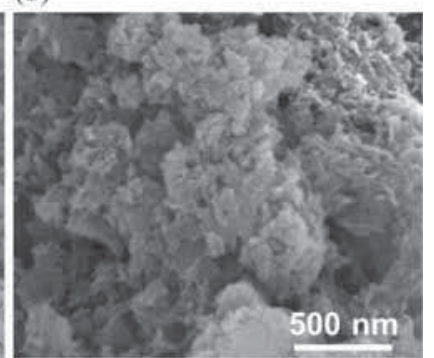

(d)

Figure 2. HRSEM images of $\mathrm{Al}_{2} \mathrm{O}_{3}$ nanoparticles at (a) lower and (b) higher magnifications and Gly@ $\mathrm{Al}_{2} \mathrm{O}_{3}$ nanoparticles at (c) lower and (d) higher magnifications.

The higher size observed here in comparison to the value obtained in XRD results could be due to the gold coating on the particles as well as the agglomeration of the particles. In the absence of surface coating in $\mathrm{Al}_{2} \mathrm{O}_{3}$ nanoparticles, the attractive force between the nanoparticles increases due to the increase in the large surface area to volume ratio and the nanoparticles are agglomerated in order to reduce the surface energy [18]. HRSEM image of the Gly@ $\mathrm{Al}_{2} \mathrm{O}_{3}$ nanoparticles shows that the particles are interconnected thereby forming layer or sheath-like structures rather than typical agglomeration. As the $\mathrm{Al}_{2} \mathrm{O}_{3}$ nanoparticles are functionalized through interaction of $\mathrm{COO}^{-}$group in glycine
$[19,23]$, agglomeration is prevented by the electrostatic repulsion of $\mathrm{NH}_{3}^{+}$group in bi-functional glycine molecule between the Gly@ $\mathrm{Al}_{2} \mathrm{O}_{3}$ nanoparticles. Nevertheless, the interionic interactions between the like-charged Gly@ $\mathrm{Al}_{2} \mathrm{O}_{3}$ nanoparticles could attract individual particles and form layer or sheath-like structures [24]. Here, the individual particles are not difficult to visualize. This may be due to the presence of glycine on the surface of alumina nanoparticles, which lead to the weak interaction of one particle with the other through interionic interactions. The EDX spectra of $\mathrm{Al}_{2} \mathrm{O}_{3}$ and Gly@ $\mathrm{Al}_{2} \mathrm{O}_{3}$ nanoparticles are shown in figure 3a and $b$, respectively. This confirms the presence of only $\mathrm{Al}$ and $\mathrm{O}$ for alumina nanoparticles while $\mathrm{C}, \mathrm{N}, \mathrm{O}$ and $\mathrm{Al}$ for Gly@ $\mathrm{Al}_{2} \mathrm{O}_{3}$ nanoparticles. The peak around $2 \mathrm{eV}$ in both the EDX spectra corresponds to gold arising from sample preparation for the HRSEM analysis.

\subsection{Interaction of $\mathrm{Gly} @ \mathrm{Al}_{2} \mathrm{O}_{3}$ with collagen}

Functionalization of $\mathrm{Al}_{2} \mathrm{O}_{3}$ nanoparticles with glycine was carried out at $\mathrm{pH}$ around 6.5 , where glycine is in dipole or zwitterionic $\left({ }^{+} \mathrm{H}_{3} \mathrm{~N}-\mathrm{CH}_{2}-\mathrm{COO}^{-}\right)$form. It is known that the interaction of glycine with $\mathrm{Al}_{2} \mathrm{O}_{3}$ nanoparticles is through $\mathrm{COO}^{-}$group of the glycine [19,23]. Figure $4 \mathrm{a}$ shows the selected range FT-IR spectra of the pure glycine and Gly@ $\mathrm{Al}_{2} \mathrm{O}_{3}$ nanoparticles for better visualization and comparison. It is seen that the $\mathrm{COO}^{-}$and $\mathrm{CH}_{2}$ bands in the Gly@ $\mathrm{Al}_{2} \mathrm{O}_{3}$ nanoparticles are blue shifted to higher wavenumber in comparison to pure glycine, which confirms the interaction of glycine with $\mathrm{Al}_{2} \mathrm{O}_{3}$ nanoparticles through $\mathrm{COO}^{-}$group in accordance with earlier reports [19,23]. Further, the TGA curve of Gly@ $\mathrm{Al}_{2} \mathrm{O}_{3}$ nanoparticles displays that nearly $50 \%$ glycine is attached to the $\mathrm{Al}_{2} \mathrm{O}_{3}$ nanoparticles, as seen from figure $4 \mathrm{~b}$. These results suggest that the Gly@ $\mathrm{Al}_{2} \mathrm{O}_{3}$ nanoparticles should possess positive charge on the surface owing to the $\mathrm{NH}_{3}^{+}$group in bi-functional glycine 


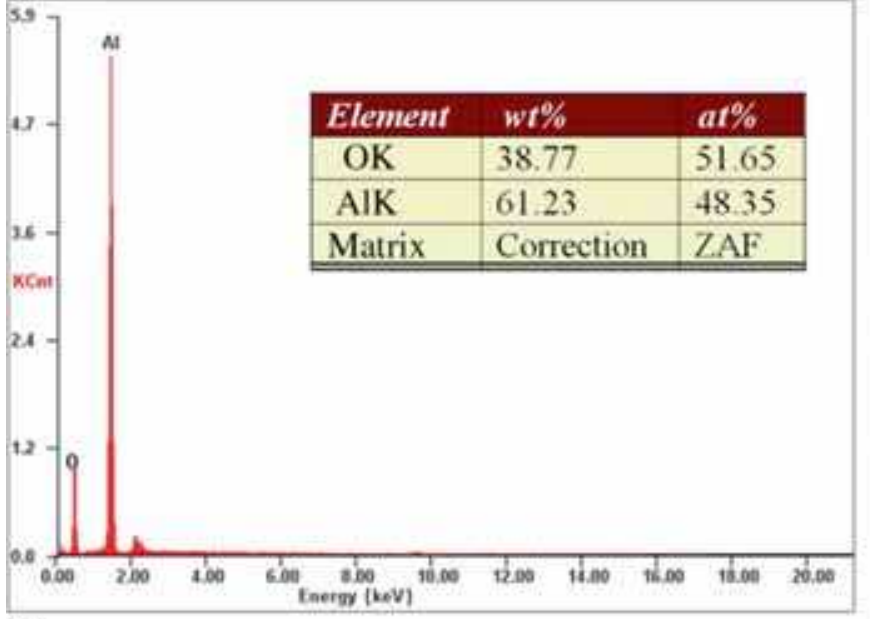

(a)

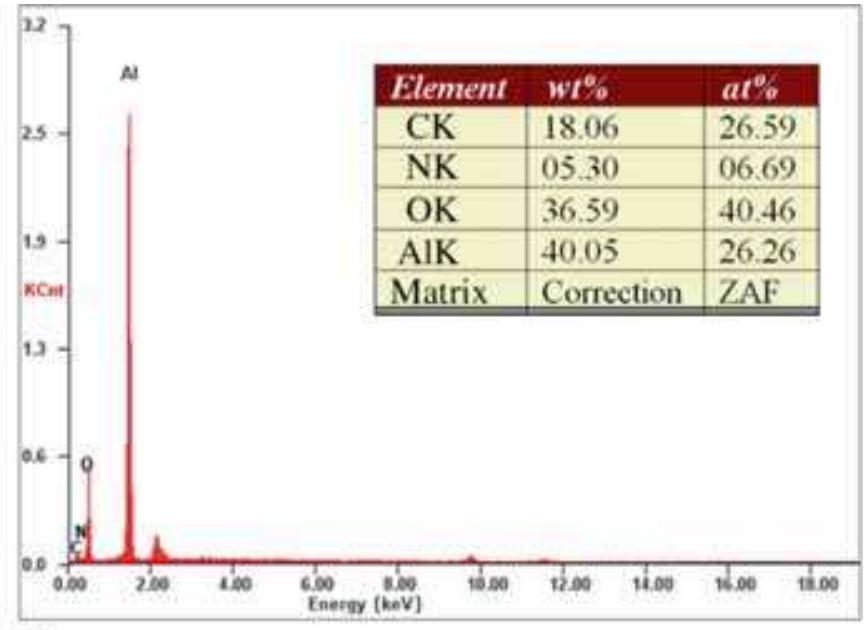

(b)

Figure 3. EDX spectra of (a) $\mathrm{Al}_{2} \mathrm{O}_{3}$ and (b) Gly@ $\mathrm{Al}_{2} \mathrm{O}_{3}$ nanoparticles.

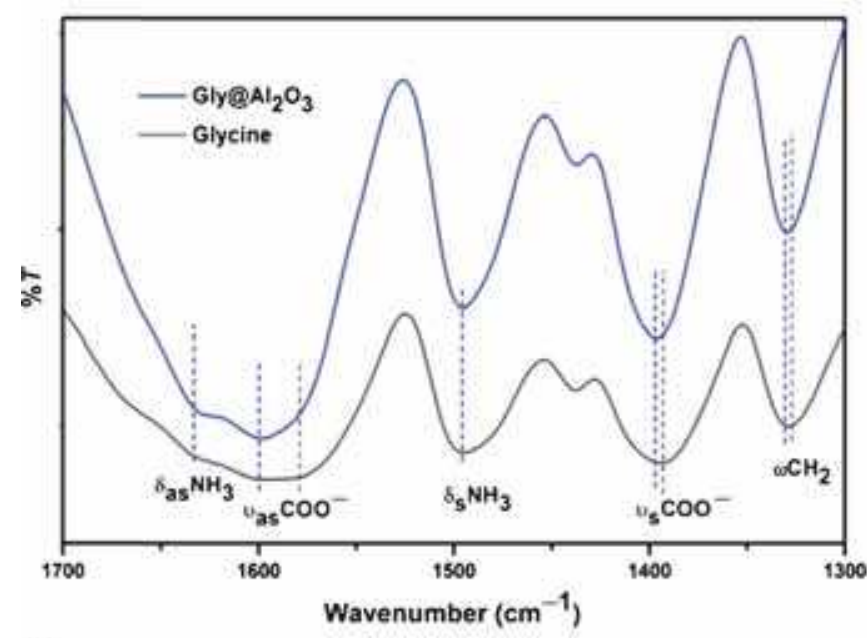

(a)

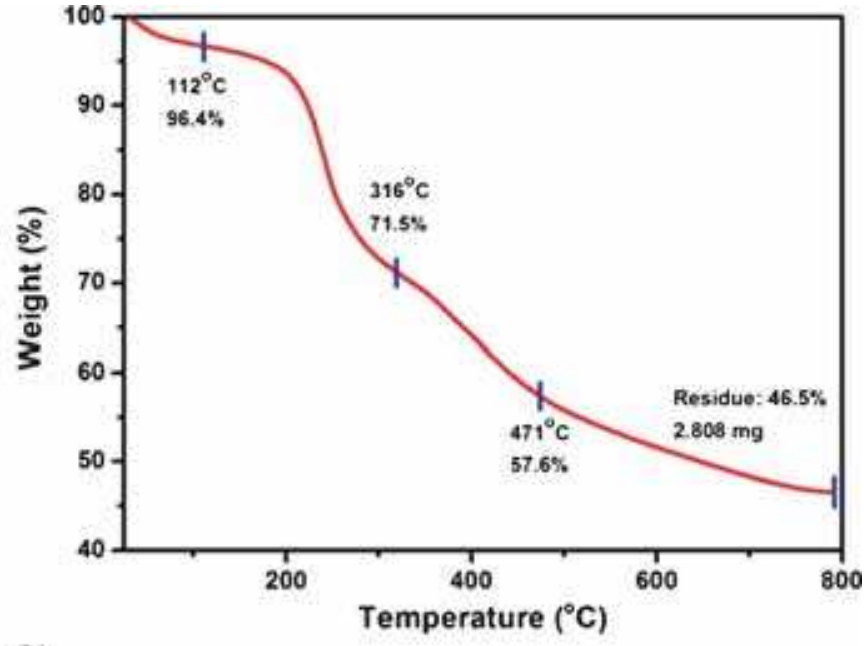

(b)

Figure 4. (a) Selected range FT-IR spectra of the pure glycine and $\mathrm{Gly}_{0} \mathrm{Al}_{2} \mathrm{O}_{3}$ nanoparticles and (b) TGA curve of $\mathrm{Gly}_{\mathrm{A}} \mathrm{Al}{ }_{2} \mathrm{O}_{3}$ nanoparticles.

molecule coated on the nanoparticles. Thus, it is expected that the $\mathrm{NH}_{3}^{+}$groups of glycine on the surface of Gly @ $\mathrm{Al}_{2} \mathrm{O}_{3}$ nanoparticles can interact with $\mathrm{COO}^{-}$groups of side chain functional groups of collagen molecules through ionic or electrovalent linkages.

FT-IR spectra of collagen, collagen interacted with $\mathrm{Al}_{2} \mathrm{O}_{3}$ and Gly@ $\mathrm{Al}_{2} \mathrm{O}_{3}$ nanoparticles are shown in figure 5a. The characteristic amide I, amide II, and amide III bands of collagen are seen at 1645,1540 and $1240 \mathrm{~cm}^{-1}$, respectively. These bands are in agreement with the earlier report [25]. The peak broadening at $500-800 \mathrm{~cm}^{-1}$ for nanoparticle interacted samples is ascribed to the presence of alumina nanoparticles. In the collagen interacted with Gly@ $\mathrm{Al}_{2} \mathrm{O}_{3}$ nanoparticles, the glycine peaks are not distinctly visible especially those present between 500 and $1000 \mathrm{~cm}^{-1}$. This may be due to the fact that collagen itself made up of several amino acids including glycine and the amount of glycine coated on the interacted Gly@ $\mathrm{Al}_{2} \mathrm{O}_{3}$ nanoparticles is very low compared with collagen.

To understand the thermal stability of collagen nanocomposites prepared in ethanol medium, wet samples of collagen interacted with $\mathrm{Al}_{2} \mathrm{O}_{3}$ and $\mathrm{Gly}_{\mathrm{al}} \mathrm{Al}_{2} \mathrm{O}_{3}$ nanoparticles were analysed using DSC and the results are shown in figure 5 b. It is well known that wet collagen shrinks irreversibly around $65^{\circ} \mathrm{C}$ when heated in the presence of water, which is known as shrinkage temperature or hydrothermal stability [7]. The interaction of neat $\mathrm{Al}_{2} \mathrm{O}_{3}$ nanoparticles with collagen decreases the shrinkage temperature to $60^{\circ} \mathrm{C}$ in spite of the use of ethanol medium in the place of water. It is known that aluminium reversibly reacts with collagen in water medium and it is washed out of treated skin matrix when soaked in water [7]. This may be the reason behind 


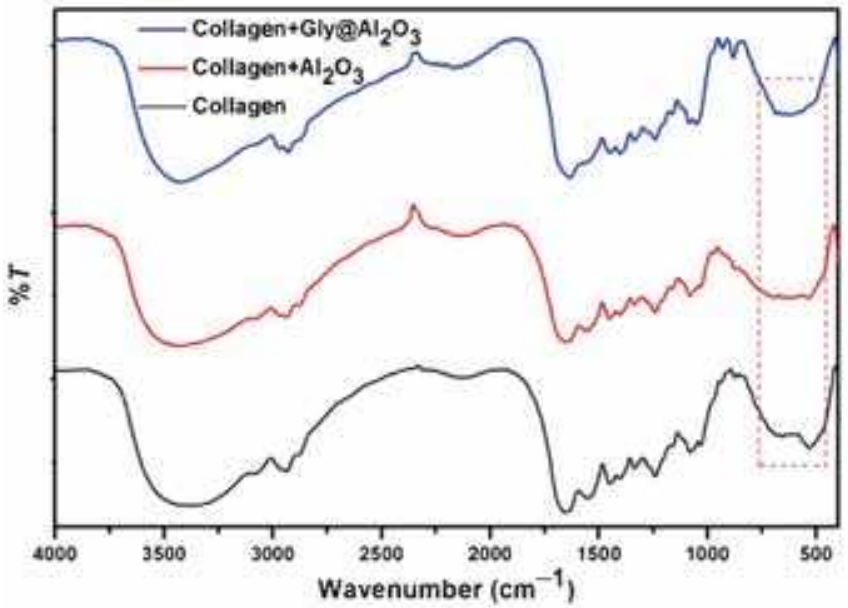

(a)

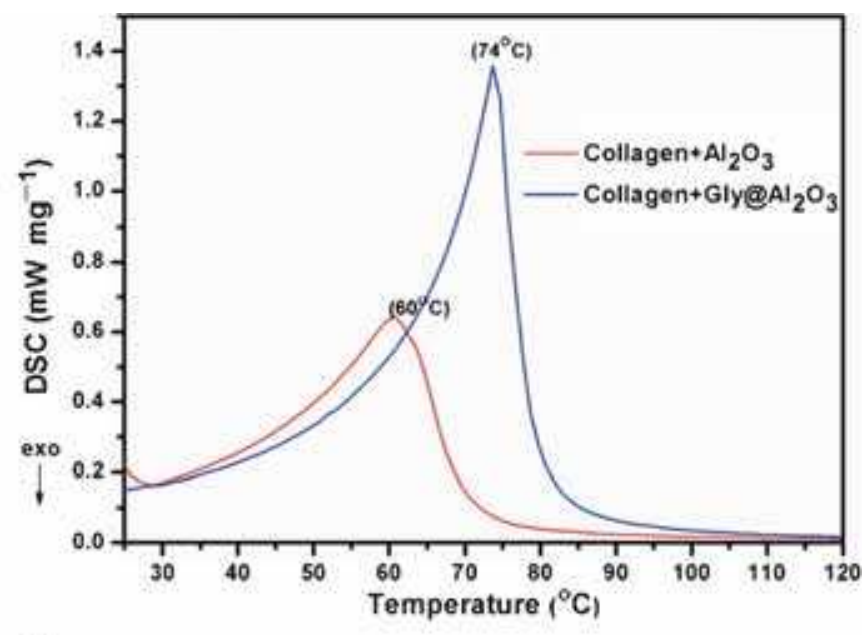

(b)

Figure 5. (a) FT-IR spectra and (b) DSC traces of collagen interacted with $\mathrm{Al}_{2} \mathrm{O}_{3}$ and $\mathrm{Gly}_{0} @ \mathrm{Al}_{2} \mathrm{O}_{3}$ nanoparticles.

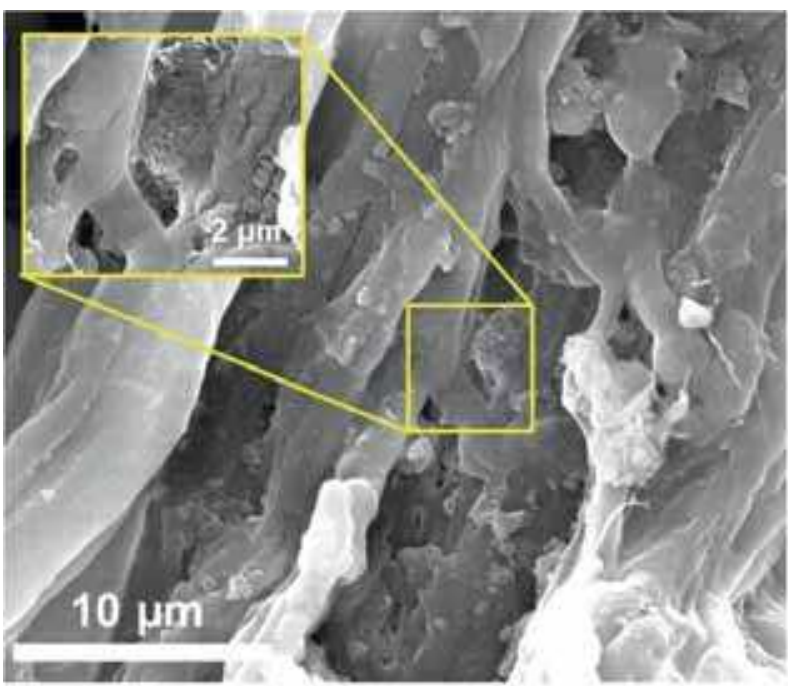

(a)

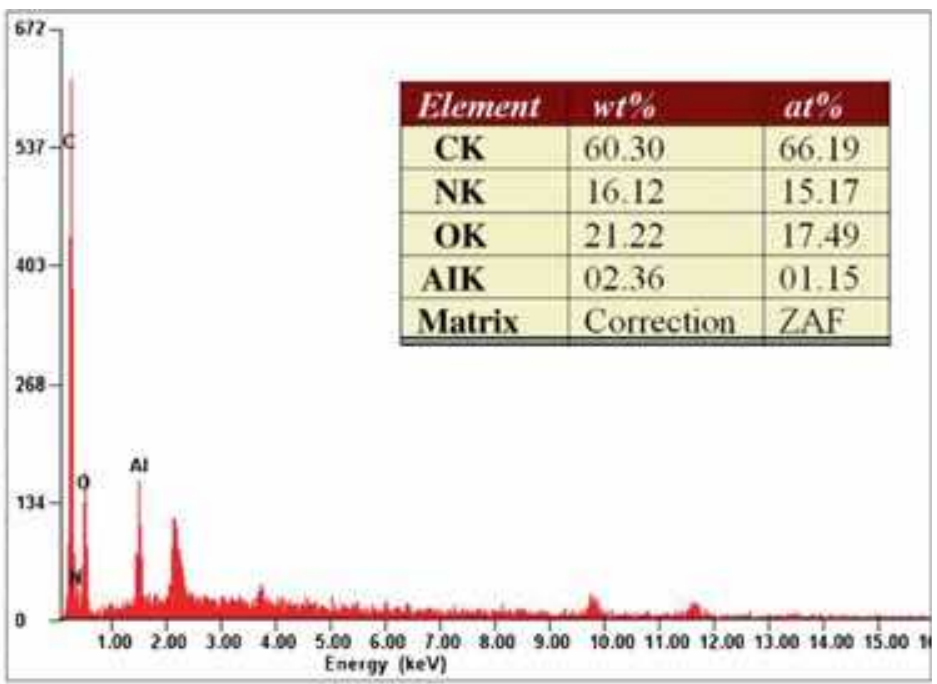

(b)

Figure 6. (a) HRSEM image and (b) EDX spectrum of collagen interacted with Gly@ $\mathrm{Al}_{2} \mathrm{O}_{3}$ nanoparticles. Inset shows the magnified view of the select portion of figure $5 \mathrm{a}$.

the low shrinkage temperature observed for the collagen treated with neat $\mathrm{Al}_{2} \mathrm{O}_{3}$ nanoparticles. However, Gly@ $\mathrm{Al}_{2} \mathrm{O}_{3}$ nanoparticles increase the shrinkage temperature of collagen to $74^{\circ} \mathrm{C}$ as shown in figure $5 \mathrm{~b}$. This can be attributed to the ionic linkage of $\mathrm{NH}_{3}^{+}$group in glycine molecule coated on the Gly@ $\mathrm{Al}_{2} \mathrm{O}_{3}$ nanoparticles with the $\mathrm{COO}^{-}$groups of side chain functional groups of collagen molecules as explained above. HRSEM image of the collagen interacted with Gly@ $\mathrm{Al}_{2} \mathrm{O}_{3}$ nanoparticles is shown in figure 6a. It can be seen that the Gly@ $\mathrm{Al}_{2} \mathrm{O}_{3}$ nanoparticles are present on the surface of the collagen fibres. The magnified view, seen as inset, from the selected portion of figure 6 a substantiates this observation. The EDX spectrum of collagen interacted with Gly@ $\mathrm{Al}_{2} \mathrm{O}_{3}$ nanoparticles also confirms the presence of aluminium-based nanoparticles on the surface of collagen (figure 6b).

\section{Conclusion}

In summary, alumina nanoparticle and glycine functionalized $\mathrm{Al}_{2} \mathrm{O}_{3}$ molecule having a bi-functional group were synthesized. XRD and FT-IR analysis reveal the presence of $\gamma-\mathrm{Al}_{2} \mathrm{O}_{3}$ and $\gamma$-glycine in the Gly@ $\mathrm{Al}_{2} \mathrm{O}_{3}$ nanoparticles. HRSEM analysis shows that the Gly@ $\mathrm{Al}_{2} \mathrm{O}_{3}$ nanoparticles are inter-connected rather than agglomerated unlike neat $\mathrm{Al}_{2} \mathrm{O}_{3}$ nanoparticles. The as-synthesized $\mathrm{Al}_{2} \mathrm{O}_{3}$ and Gly@ $\mathrm{Al}_{2} \mathrm{O}_{3}$ nanoparticles were used to stabilize the collagen fibres. The results show that Gly@ $\mathrm{Al}_{2} \mathrm{O}_{3}$ nanoparticles increase the thermal stability of collagen up to $74^{\circ} \mathrm{C}$. The study reveals that the stabilization of collagen using Gly@ $\mathrm{Al}_{2} \mathrm{O}_{3}$ nanoparticles has potential for applications in leather making, biomedicine and cosmetics. 


\section{Acknowledgements}

Financial support from CSIR under XIIth plan project 'Research Initiatives for Waterless Tanning' (RIWTCSC0202) is greatly acknowledged. CSIR-CLRI Communication no. 1156.

\section{References}

[1] Ramachandran G N and Kartha G 1955 Nature 176593

[2] Usha R and Ramasami T 1999 Thermochim. Acta 33817

[3] Eyre D and Wu J-J 2005 Collagen (Berlin, Heidelberg: Springer) Vol 247, p 207

[4] Chan B P and So K F 2005 J. Biomed. Mater. Res. A 75A 689

[5] Thanikaivelan P, Geetha V, Rao J R, Sreeram K J and Nair B U 2000 J. Soc. Leather Technol. Chem. 8482

[6] Chakravorty H P and Nursten H E 1958 J. Soc. Leather Technol. Chem. $\mathbf{4 2} 2$

[7] Covington A D 1997 Chem. Soc. Rev. 26111

[8] Raghava Rao J, Chandrababu N K, Muralidharan C, Nair B U, Rao P G and Ramasami T 2003 J. Clean. Prod. 11591

[9] www.un.org, 2002

[10] Krishnamoorthy G, Sadulla S, Sehgal P K and Mandal A B 2012 J. Hazard. Mater. 215-216 173

[11] Manfred R, Eckhard W, Björn J and Helmut G $2012 \mathrm{~J}$. Supercrit. Fluid 66291

[12] Mo X, An Y, Yun C-S and Yu S M 2006 Angew. Chem. Int. Ed. 452267
[13] Sisco P N, Wilson C G, Mironova E, Baxter S C, Murphy C J and Goldsmith E C 2008 Nano Lett. 83409

[14] Fan H, Li L, Shi B, He Q and Peng B 2005 J. Am. Leather Chem. Assoc. 10022

[15] Thanikaivelan P, Narayanan N T, Pradhan B K and Ajayan P M 2012 Sci. Rep. 2230

[16] Alliraja C, Rao J R and Thanikaivelan P 2015 RSC Adv. 5 20939

[17] Castaneda L, Valle J, Yang N, Pluskat S and Slowinska K 2008 Biomacromolecules 93383

[18] Gupta A K and Gupta M 2005 Biomaterials 263995

[19] Feitoza N C, Gonçalves T D, Mesquita J J, Menegucci J S, Santos M-K, Chaker J A, Cunha R B, Medeiros A M M, Rubim J C and Sousa M H 2014 J. Hazard. Mater. 264 153

[20] Pradhan A C, Parida K M and Nanda B 2011 Dalton Trans. 407348

[21] Ali Ahamed S Z, Dillip G R, Raghavaiah P, Mallikarjuna K and Deva Prasad Raju B 2013 Arab. J. Chem. 6 429

[22] Ma C, Chang Y, Ye W, Shang W and Wang C 2008 J. Colloid. Interface Sci. 317148

[23] Tzvetkov G, Koller G, Zubavichus Y, Fuchs O, Casu M B, Heske C, Umbach E, Grunze M, Ramsey M G and Netzer F P 2004 Langmuir 2010551

[24] Inagaki T, Aono S, Nakano H and Yamamoto T 2014 J. Phys. Chem. B 1185499

[25] Song J-H, Kim H-E and Kim H-W 2007 J. Biomed. Mater. Res. B 83B 248 